\section{Germany puts faith in big guns as science ministry feels pinch}

Quirin Schiermeier, Munich

Germany's research spending will be trimmed next year by about $€ 100$ million (US\$120 million), dashing hopes that science can escape the impact of the nation's growing fiscal difficulties.

In a plan scheduled to be approved by parliament on 28 November, Germany's main research agency, the DFG, and three large research organizations, including the Max Planck Society (MPS), will each get a budget increase of $3 \%$ in 2004 lifting this year's budget freeze.

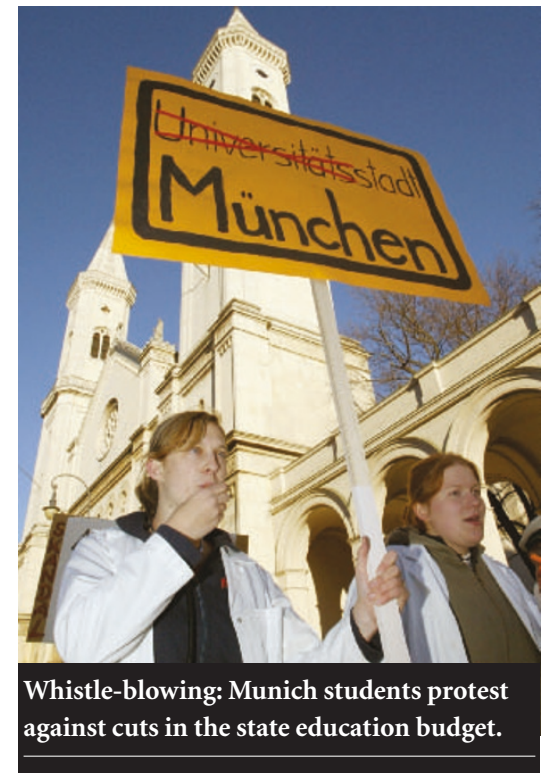

The DFG and MPS will receive about $€ 1.3$ billion and $€ 960$ million, respectively, from the research budget. But the overall budget of the education and research ministry, which also provides grants in areas such as biotechnology and genetics, will be cut by $€ 100$ million - about $4 \%$.

The cuts at the research ministry will "drastically increase" the demand for DFG grants, says Ernst-Ludwig Winnacker, the agency's president.

Dark clouds are also gathering over universities in Bavaria, Germany's richest state, where science has enjoyed strong support. On 20 November, tens of thousands of students in Munich and other cities protested against state plans to cut university budgets by $10 \%$ next year.

"In the long term this would force us to close several institutes," says Bernd Huber, the rector of Ludwig-Maximilians University in Munich, which has to save $€ 30$ million next year. "But in the short term, there's nothing we can do but cease to renew young scientists' contracts."

\section{GloFish casts light on murky policing of transgenic animals}

\section{Jonathan Knight, San Francisco}

A fluorescent fish that will be on sale in pet stores has exposed a gaping hole in the United States' ability to regulate the sale of genetically engineered animals.

Despite growing concern over the potential risks of releasing such animals into the environment, the transgenic GloFish looks set to go on sale on 5 January without any federal regulatory approval.

Watchdog groups and some biologists warn that this sets a worrying precedent. Some aquarium fish are invariably released into the wild, they say, and even if the GloFish is safe, the floodgates will be opened to riskier transgenic pets. "This isn't just one little fish, it's a parade," says Margaret Mellon of the Union of Concerned Scientists in Washington DC.

But the company preparing to sell the fish, Yorktown Technologies of Austin, Texas, says that it has consulted numerous scientists to ensure that the GloFish does not pose a threat. "I would encourage any company following us to do the same," says chief executive Alan Blake.

No federal agency has claimed jurisdiction for such animals, because the US government has no specific regulations for the use of transgenic organisms, having decided in 1986 simply to adapt existing rules. The resulting framework divides jurisdiction among three agencies - the Environmental Protection Agency (EPA), the Food and Drug Administration (FDA) and the Department of Agriculture-depending on the gene inserted.

Years later, when Aqua Bounty Farms of Waltham, Massachusetts, proposed inserting a growth-hormone gene into salmon, the rules were stretched to cover the fish by classifying any added protein that changes an animal's function as a drug to be regulated by the FDA. The agency is now considering Aqua Bounty's application to farm the transgenic salmon.

But no rule-stretching has yet been done to cover pet fish. Blake says he contacted the FDA, which told him that the GloFish does not fall under FDA jurisdiction. He reports similar responses from the EPA, the Department of Agriculture and the Fish and Wildlife Service.

Scientists who have seen data on the GloFish say it does not seem to pose an environmental threat. It was developed by Zhiyuan Gong at the National University of Singapore, who plans to link the colour genes to genetic elements that respond to pollu- tants such as heavy metals, to monitor water quality. When Gong tested the fish's reproductive success in mixed populations, the transgenic fish had fewer offspring than wild ones.

That suggests they are safe for release, says William Muir, an aquaculture expert at Purdue University in West Lafayette, Indiana, one of several scientists providing Blake with unpaid advice. "You might think that something glowing would have an advantage, but it has the reverse effect," he says.

But Muir says that such unexpected findulation of transgenic animals, because it is impossible to predict a transgene's effects. Muir was the first to describe the 'Trojan gene' effect, in which an introduced gene spreads rapidly in a population while at the same time reducing overall survival rates (see Nature 406, 10-12;2000). "There should definitely be a regulatory process," he says.

The only government review so far is taking place in California, where in May the state's Department of Fish and Game banned the possession, sale and transport of genetically engineered fish. Yorktown has applied for an exception for the GloFish, and the department is preparing to present a recommendation at the next Fish and Game Commission meeting on 4 December.

But federal involvement is essential, says Peter Jenkins of the Center for Food Safety in Washington DC, one of five groups petitioning the FDA to regulate the fish. "Glowing reviews by a few scientists are not enough," he says. "There should be a formal process."

Anne Kapuscinski, a fisheries expert at the University of Minnesota, Twin Cities, says the GloFish is an opportunity for the FDA to establish its authority in the transgenic pet trade. Approval would be fairly straightforward, she thinks. "It behoves the government to act as proactively as possible," she says. "People are losing trust in the process." ings only underscore the need for careful reg-

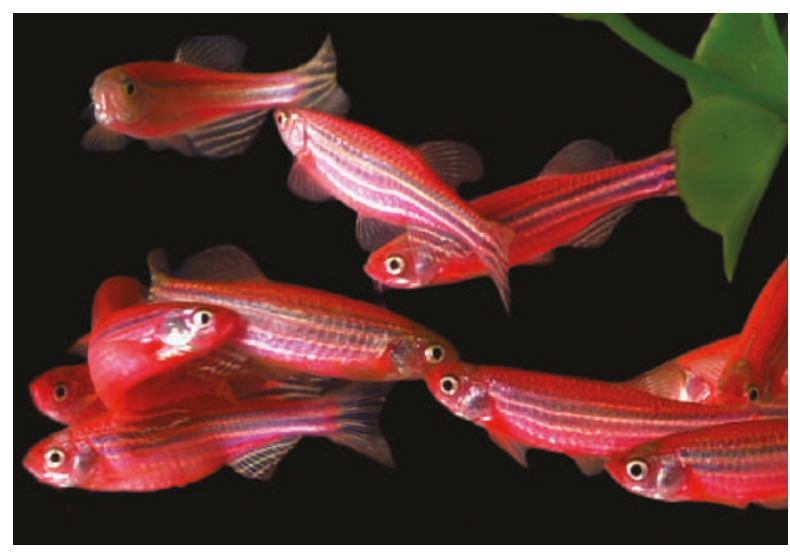

Glowing review: watchdogs want tighter rules for transgenic pets. 